\title{
ON RAISING OSIRIS IN 1 CORINTHIANS 15
}

\author{
Nicholas Perrin
}

\begin{abstract}
Summary
This article examines possible comparisons between Paul's teaching on resurrection in 1 Corinthians 15 and the Egyptian myth of resurrection. This involves not only a consideration of the isolated parallels, but an investigation of the degree of coherence between Paul's theological framework and the broad perspective of the Osirians. Recent arguments for Osirian influence in Paul, though superficially plausible, are unsuccessful because they fail to understand Paul and the Egyptians on their own conceptual terms.
\end{abstract}

\section{Introduction}

The suggestion that Paul's theology of resurrection was developed on the basis of Osirian concepts of the afterlife has had an enduring shelflife. ${ }^{1}$ The proposal is generally made on the basis of particular parallels. For example, Bostock maintains that Paul's comparison between the resurrection body and a germinating seed (1 Cor. 15:36-49) - the latter image being closely tied to the Egyptian god Osiris - is evidence that Osirian categories stand behind the apostle's maturing thought. ${ }^{2}$ Perhaps more significant is the frequent claim that Paul's

1 As early as 1876, John Stuart Glennie ('Christ and Osiris', Reprints from 'In the Morningland' [London: Scott, 1876]: 10) calls Christianity a 'a transformed Osirianism'. See also Torgny Säve-Söderbergh, Pharaohs and Mortals (ET; Indianapolis, Ind.: Bobbs-Merrill, 1961): 256; Roland G. Bonnel and Vincent A. Tobin, 'Christ and Osiris: A Comparative Study', in Sarah I. Groll, ed., Pharaonic Egypt (Jerusalem: Magnes, 1985): 1-29; Giuseppe Masi, Lo spiritualismo egiziano antico: Il pensiero religioso egiziano classico (Bologna: Editrice, 1994); Ramez Atallah, 'The Objective Witness to Conscience: An Egyptian Parallel to Romans 2:15', Evangelical Review of Theology 18 (1994): 204-13; Ahmed Osman, Out of Egypt: The Roots of Christianity Revealed (London: Century, 1998); D. Gerald Bostock, 'Osiris and the Resurrection of Christ', ExpTim 112 (2001): 265-71.

2 Bostock, 'Resurrection of Christ': 270; cf. Bonnel \& Tobin, 'Christ and Osiris': 25. 
'spiritual body' (1 Cor. 15:44) is a direct appropriation of the Egyptian notion of the $s a h u .^{3}$ Finally, Paul understands Christ to be a corporate personality who embodies and represents redeemed humanity and that the same role and functions appear to be predicated of Osiris. ${ }^{4}$ Since Osirian belief predates Christianity by several millennia, these arguments seem to offer a plausible account of Christian origins.

Of course, whether it is a likely account is a different matter, for similarities by themselves do not prove interdependence. Sound historical methodology requires more than gathering isolated parallels: there must be some weighing of the parallels on their own merits, as well as some consideration of the larger conceptual frameworks to which they relate. 5 The proper questions, in other words, are (1) whether isolated comparisons between Paul's teaching on resurrection and the Egyptian myth provide grounds for supposing interdependence, and (2) whether there is some degree of structural coherence between Paul's larger theological framework - his 'convictional world' - and the broad perspective of the Osirians. If the case for Paul's integration of the Osiris myth into his developing theology is to be persuasive, it must speak at least in some measure to both of these issues.

\section{Shared Motifs in Paul and Osirianism}

Comparisons between 1 Corinthians 15 and the myth of Osiris have shown that Paul and the Egyptians appear to use similar images and concepts in their respective descriptions of the afterlife. In both cases there is (1) the use of seed imagery to represent the idea of resurrection; (2) the notion of a post-mortem 'spiritual body'; and (3) language that may be interpreted as signifying a mystical union with the divinity. Each of these parallels deserves closer attention.

Given the prevalence of seed imagery in Egyptian art, texts and material culture, there is a certain attractiveness to the idea that

3 Masi, Pensiero religioso: 243-45, 252; Bostock, 'Resurrection of Christ': 270.

4 Masi, Pensiero religioso: 242, 256; Atallah, 'An Egyptian Parallel': 208 n6; Bostock, 'Resurrection of Christ': 271.

5 These two points roughly correspond to what Claas Bleeker ('The Contribution of the Phenomenology of Religion to the Study of the History of Religions', in Problems and Methods of the History of Religions [SHR 19; Leiden: Brill, 1972]: 41) refers to as the 'theoria' and 'logos' of religious phenomena. The former has to do with the essence and meaning of discrete religious facts; the latter has to do with the inner logic or structure to which those facts belong. 
1 Corinthians 15 is partially based on the Egyptian notion 'that a person is able to germinate in the manner of a plant from its seed' ${ }^{6}$ Among the Egyptians there is a long-standing connection between the god of the dead and barley grain. ${ }^{7}$ In the Pyramid Texts of the third millennium BCE one reads: 'Rise from your left side, turn on your right side ... I have grown barley. I have reaped spelt. I have made offerings for our feasts ...' (Pyr. 1747-48). ${ }^{8}$ In rites of royal succession during the Middle Kingdom (ca. 2040-1650 BCE) the act of striking barley grain served as a ritualistic representation of Osiris's death at the hands of his brother Seth. ${ }^{9}$ This close tie between barley and Osiris continues through the New Kingdom down into Ptolemaic times. ${ }^{10}$

But that this association directly relates to Paul's analogy between the body and seed in 1 Corinthians 15:35-44 is difficult to prove. Paul and the Egyptians were not the only ones to connect sprouting seed with the idea of resurrection and rebirth. The gods Tammuz (Mesopotomia), Adonis (Syria), and Attis (Phrygia) are all said to undergo a resurrection of sorts; notably, all of these, like Osiris, are also gods of vegetation. ${ }^{11}$ It is understandable how, in these agrarian settings, seed

6 Bostock, 'Resurrection of Christ': 270. Cf. Bonnel and Tobin, 'Christ and Osiris': 25.

7 James Henry Breasted (Development of Religion and Thought in Ancient Egypt [New York: Harper, 1959]: 23) is representative of the view that the numerous depictions of grain sprouting out of Osiris's body symbolise his role as 'the imperishable principle of life ... The ever-waning and reviving life of the earth, sometimes associated with the life-giving waters, sometimes with the fertile soil, or again discerned in vegetation itself - that was Osiris.' The precise origins of Osiris's role as fertility god are a matter of dispute. J. Gwyn Griffiths (The Origins of Osiris and His Cult [SHR 40; Leiden: Brill, 1980]: 163), for example, traces this to his connection with Orion; Edmund Hermsen (Lebensbaumsymbolik im alten Ägypten [Arbeitsmaterialien zur Religionsgeschichte 5; Köln: Brill, 1981]: 144-50) argues that Osiris came to be regarded as the source of life through his identification with the 'tree of life'.

8 Translation from R. O. Faulkner, The Ancient Egyptian Pyramid Texts (Oxford: Clarendon, 1969).

9 See Kurt Sethe, Dramatische Texte zu altägyptischen Mysterienspeilen (Untersuchungen zur Geschichte und Altertumskunde Ägyptens 10; Hildesheim: Olms, 1964 [1928]): 134; also Henri Frankfort, Kingship and the Gods: A Study of Near Eastern Religion as the Integration of Society and Nature (Oriental Institute Essay; Chicago: Chicago University, 1948): 123.

10 As witnessed by descriptions in the Dendera texts which recount agrarian festival taking place in the month of Choiak. See Françoise Dunand, 'Les mystères égyptiens aux époques hellénistique et romaine’, in Mystères et syncrétismes (Études d’Histoire des Religions 2; Paris: Geuthner, 1975): 9-62, esp. 13-26.

11 But see Edwin M. Yamauchi, 'Tammuz and the Bible', JBL 84 (1965): 290, where clear, pre-Christian evidence for the resurrection of these gods is said to be lacking. 
imagery was consistently employed to symbolise death and rebirth. But the very aptness of the metaphor - the archetypal connection between seeds and rebirth - warns against hasty conclusions regarding dependence on any single one of these mythic narratives. In fact, there is no reason to suspect that Paul's choice of metaphor was derivative from Egyptian mythology: it is at least as likely that the comparison between seed and resurrection presented itself naturally to the author of 1 Corinthians, or came down to him through the Jesus tradition (Mark 4:26-29; John 12:23-25).

Another alleged point of comparison between Paul and the Osirian myth bears on the nature of the resurrected body. For Paul, as for the Egyptians, the future body enjoyed a kind of glorified status. According to E. A. Wallis Budge, writing more than a century ago, the Egyptians did not see the entombed body as

inoperative, for by the prayers and ceremonies on the day of burial it is endowed with the power of changing into a sahu, or spiritual body ... The word sahu indicates a body, which has obtained a degree of knowledge and power and glory whereby it becomes henceforth lasting and incorruptible. ${ }^{12}$

Budge's description has in turn provided the basis for the claim of more recent writers that Paul's 'spiritual body' was a reworking of the Egyptian sahu. ${ }^{13}$ Of course, given Budge's language, the comparison between Paul's 'spiritual body' and the sahu is not easily missed.

But two significant problems attend Budge's analysis of the sahu. ${ }^{14}$ First, Budge may be faulted for his unqualified use of Western anthropological categories in elucidating non-Western anthropological terms. If the sahu is to be termed 'spirit body', then it must also be stated that for the Egyptians all physical existence was at once material and spiritual. The sharp spiritual-physical dichotomy, intrinsic to postCartesian Western thought, simply does not apply to Egyptian

12 Budge, The Book of the Dead: The Papyrus of Ani in the British Museum (London: 1895): lix-lx.

13 See Masi, Pensiero religioso: 251-52, also 243-45; Bostock, 'Resurrection of Christ': 270.

14 Lexicographers more recent than Budge simply define sahu as 'mummy'; see WÄS, 4.52-53; CDME: 215. See also Gertrud Thausing, Der Auferstehungedanke in Ägyptischen religiosen Texten (Leipzig: Harrassowitz, 1943): 16; John H. Taylor, Death and Afterlife in Ancient Egypt (Chicago: University of Chicago, 2001): 16. 
anthropology. ${ }^{15}$ Thus, the translation of 'spirit body' is misleading inasmuch as it implies an extraordinary fusion or coalescing of 'spirit' and 'body', while in Egyptian thought these aspects of the human personality were never considered entirely separate in the first place.

Secondly, Budge is again misleading when he describes the sahu as 'henceforth lasting and incorruptible'. Of course, ancient Egyptian anthropology has been notoriously difficult to understand, much less describe, and the sahu, as one term among several signifying the human person, is no exception. Nonetheless, the difficulties do not altogether prevent our situating the sahu vis-à-vis Paul's 'spiritual body'. It is certainly clear, as even Budge's own translation elsewhere shows, that the sahu is subject to various pains and tortures of the underworld judgement, and this places it at quite a remove from Paul's 'incorruptible body'. ${ }^{16}$ The very point of Paul's contrast between the incorruptible body and the corruptible body lies precisely in the fact that the former (as opposed to the latter) is free of destruction or harm of any kind (1 Cor. 15:42); ${ }^{17}$ in the Egyptian understanding the mummified body was constantly subject to possible injury. The dissimilarities between Paul's 'incorruptible body' and the sahu could hardly be greater. Now widely considered outdated and often inaccurate, Budge's writings must be used with caution. His descriptions of Egyptian thought, because they are so indebted to modern, Western categories, should not then be used as a basis for reading Egyptian thought into writers like Paul, who so heavily influenced the genesis of those categories.

A third comparison between Pauline teaching and the Osirian myth is the fact that both use language that suggests identification with the deity. The earliest Egyptian texts show the expectation that the dead pharaoh would 'become Osiris', and over the centuries the masses

15 The point is made particularly well in Ragnhild Bjerre Finnestad, 'On Transposing Soul and Body into a Monistic Conception of Being: An Example from Ancient Egypt', Religion 16 (1986): 359-73.

16 'Hail, Ra, thou who goest round about in the sky, I say, O Osiris in truth, that I am the Sahu (i.e. the spirit-body) of the god, and I beseech thee not to let me be driven away, nor to be case upon the wall of blazing fire.' (Book of the Dead 147.7b-12 in Budge: 402-03). See also Jan Zandee, Death as an Enemy, According to Ancient Egyptian Conceptions (SHR 5; Leiden: Brill, 1960): 174.

17 As Anthony C. Thiselton (The First Epistle to the Corinthians [NIGTC; Grand Rapids: Eerdmans, 2000]: 1272) remarks, Paul's phrase 'en aphtharsia' (1 Cor. 15:42) describes a future condition where 'destruction', 'termination', and 'mutilation' are entirely absent. 
appeared to share the same aspiration. In 1 Corinthians 15, Paul may be entertaining an analogous hope with respect to Christ (vv. 21-22), even if he conceives this union as taking place in the present life (cf. Rom. 6:5, 8:9; 1 Cor. 3:16; Gal. 2:20). That both Paul and the Osirians spoke of the possibility of merging with the deity has led some to see the two belief-systems as connected. ${ }^{18}$

At the same time a number of scholars have urged caution in interpreting the phrase 'to become Osiris'. There are at least some instances where clearly those 'who are in Osiris' (imy.w Wsir) are more exactly 'those who are in the realm of Osiris', whereby metonymically 'to become Osiris' serves as a circumlocution for entry into the underworld. ${ }^{19}$ And although Siegfried Morenz claims that there is some archaeological evidence that death brought about a merging of personality between Osiris and his devotee (Osiris NN), ${ }^{20}$ this evidence comes rather late and (as Morenz equally insists) is a clear departure from classical Egyptian thought. As a number of scholars understand it, 'to become' a god is nothing more or less than joining the company of that god or sharing his realm. ${ }^{21}$ Nor does the phrase 'to become Osiris' necessarily involve a personal interaction between Osiris and the deceased human. As Friederich Junge sees it, 'neither unio mystica nor complete identification with God is possible - not even in death in Egypt'; instead, all that dies 'becomes Osiris', including biological (plant and animal) and institutional (political or social) realities. ${ }^{22}$ The phrase 'to become Osiris' thus seems to have been a widely applied circumlocution for death; it was an idiomatic expression that reflected the Egyptian underworld belief, rooted within a pantheistic frame of reference.

18 Bostock, 'Resurrection of Christ': 271; Masi, Pensiero religioso: 242, 256.

19 Zandee, Death as an Enemy: 235.

20 Morenz, 'Das Problem des Werdens zu Osiris in der griechisch-romischen Zeit Ägyptens’, in Religions en Égypte hellénistique et romaine: Colloque de Strasbourg, 16-18 mai, 1967 (Paris: Presses Universitaires de France, 1969): 75, 77, 84.

21 See, for example, Klaus Parlasca, 'Osiris und Osirisglaube in der Kaiserzeit', in Syncrétismes dans les religions grecque et romaine (Paris: Presses Universitaires de France, 1973): 95-102; Zabkar, A Study of the Ba (SAOC 34; Chicago: University of Chicago, 1968): 151-52; Eberhard Otto, Deutsches Archäologiches Institut (Abteiliung Kairos) (Stuttgart: Kohlhammer, 1957): 195.

22 Junge, 'Isis und die ägyptischen Mysterien', in Wolfhart Westendorf, ed., Aspekte der spätägyptischen Religion (Göttinger Orientforschungen 4; Wiesbaden: Harrassowitz, 1979): 94-95. So too Bergmann, Ich bin Isis: Studien zum memphitischen Hintergrund der griechischen Isisaretalogien (Uppsala: Almquist \& Wiksell, 1968): 230; Thausing, Auferstehungedanke: 96. 
This is quite different from what Paul seems to have in mind when he speaks of being 'in Christ', which refers in a technical sense to the believer's incorporation into the person of the Messiah. ${ }^{23}$ For Paul, the state of being 'in Christ' was to be realised personally and realistically in the present life, even if this fell short of absolute co-identification. Entry 'into Christ' meant participation in a community that at once embodied and was embodied by Christ (Rom. 12:5). By contrast, for the Egyptians, 'becoming Osiris', which occurred upon entrance into the underworld, meant the cessation of interpersonal relationship and induction into an impersonal mode of existence. Finally, the effort to forge any meaningful analogy between 'becoming Osiris' and being 'in Christ' breaks down simply because the monotheistic Paul and the pantheistic Egyptians had a different understanding of the interrelationship (and possible interpenetration) between deity, humanity, and cosmos. To such broader issues I now turn.

\section{Worldview in Paul and Osirianism}

Whilst isolated parallels between Paul and the Osirian myth prove to be rather insubstantial, it is in relation to the broader issues of Weltanschaung that the comparisons between the two doctrines become most problematic. Notwithstanding the Egyptians and Paul's mutual interest in the post-mortem physical body (an important point for those wishing to make the case for an Egyptian influence on Paul), ${ }^{24}$ there are weightier points where the followers of Osiris and the apostle part ways. These becomes especially clear when due appreciation is given to the fact that the two doctrines of resurrection can only be understood on the basis of their own governing assumptions.

Without prejudging the issue at stake, that is, whether Osirian categories may have influenced the apostle subsequent to his conversion, it is at least widely acknowledged that the Damascus experience caused the apostle to formulate his beliefs anew with

23 See C. F. D. Moule, The Origin of Christology (Cambridge: Cambridge University, 1977): 62-63; James D. G. Dunn, The Theology of Paul the Apostle (Grand Rapids, Mich./Cambridge: Eerdmans, 1998): 390-412.

24 Although the point is sometimes disputed, e.g. by Dale B. Martin (The Corinthian Body [New Haven, Conn.: Yale University, 1995]: 123-29), I will assume for the sake of argument that in Paul's view the resurrection body is indeed physical. On this point, see N. T. Wright, The Resurrection of the Son of God (London: SPCK, 2003): 207-398. 
reference to a new-found Christology. ${ }^{25}$ When Paul came to the twin realisation that Jesus was both Christ and 'risen one', he considered the two disclosures to be mutually defining. Just as the fact of resurrection validated Jesus' status as the Messiah (Rom. 1:3), so too did the fact of this messiahship at least partially inform Paul's understanding of the resurrection to come (1 Cor. 15:12, 20-28, 44-49). Paul, like his contemporaries, viewed the resurrection as an event fraught with moral significance; ${ }^{26}$ unlike many of his contemporaries, Paul also found the resurrection to be christologically significant, whereby the position of those 'being raised' could not finally be separated from the character and faithfulness of the one in whom they are raised (Rom. 6:1-14; Gal. 2:20).

Paul also saw in the resurrection the final realisation of God's purposes. Although the Easter event may not have been foreseeable, it did in retrospect follow logically and perhaps even inevitably from the selfrevelation of God. Paul consistently sets forth the claim that the righteousness and faithfulness of God, both to Israel and to all of creation, receive their definitive expression in the cross and resurrection of Jesus. It is the resurrection in particular that secures not only the justification of God's people (Rom. 4:25), but also the assurance of future judgement for all, including those outside the covenant (Rom. 14:9).

Of course, Jesus' resurrection also redefined Paul's eschatological outlook. It is widely acknowledged that the pre-Christian Paul shared the viewpoint of his contemporary Jews: namely, that God would break into historical time and space so as to usher in the end of the age. But following his encounter with Christ, Paul was compelled to interpret Jesus' resurrection as the inauguration of the eschatological age which did not bring an instant end to the 'present evil age', but did decisively signal the imminence of the final eschaton.

Despite this modified eschatology, reconfigured in light of the Christ-event, Paul's vision of history remained fundamentally Jewish and, for this reason, fundamentally relevant to post-mortem specul-

25 See, for example, Seyoon Kim, The Origin of Paul's Gospel (WUNT 2; Tübingen: Mohr, 1981); N. T. Wright, The Climax of the Covenant: Christ and the Law in Pauline Theology (Minneapolis, Minn.: Fortress, 1992): passim; Richard N. Longenecker, ed., The Road from Damascus: The Impact of Paul's Conversion on His Life, Thought and Ministry (Grand Rapids: Eerdmans, 1997).

26 For summarising statements on resurrection belief in second-temple Judaism see Hans C. C. Cavallin, Life after Death: Paul's Argument for the Resurrection of the Dead in I Cor. 15 (ConBNT 7; Lund: Gleerup, 1974): 201-2; George W. E. Nickelsburg, Resurrection, Immortality, and Eternal Life in Intertestamental Judaism (HTS 26; Cambridge: Harvard University, 1972): 124. 
ation. History had awaited the coming of the Christ, and now that Christ had come, it would then await the final climax of the parousia. This also meant that the nature of the individual afterlife, whether 'in the body' or 'away from the body', was contingent upon the unfolding of certain salvation-historical events (2 Cor. 5:1-10; 1 Thess. 4:13-17). Paul commended a forward-looking hope with the expectation that at some point in time 'we will all be changed' (1 Cor. 15:51). This resurrection hope, the prospect of 'immortality and incorruptibility' (1 Cor. 15:53-54), lay not immediately after the death of the individual, but was to be located within the timetable of salvation-history. This resurrected existence (and here Paul is again consonant with his Jewish milieu) is clearly a state of being qualitatively superior to 'this life' (1 Cor. 15:19). Properly understood, then, 1 Corinthians 15 was not intended to be a treatment of the individual believer's experience of resurrection so much as a description of a cosmic timetable of events, which would also be the ground of the individual believer's hope.

The christological, covenantal, and eschatological significance of resurrection in the corpus Paulinum highlights a fundamental disjunction with the Osirian mythology. Whereas Paul pinned his hopes on certain historical realia, the person of Christ and the covenants, there was no comparable basis for hope among the follower of Osiris. Nor do we find in Osirianism anything analogous to the theodicean logic that underpins Paul's Christology and eschatology. By any account, Osiris was a cruel god who discharged his duties as tormentor quite apart from any ethical considerations, either on his part or on the part of the deceased. ${ }^{27}$ For the Egyptians, meeting Osiris meant the possibility of torture, dismemberment, annihilation - all at

27 For centuries before the time of Paul, it was ultimately by virtue of magic spells that there was any hope of overcoming the demonical powers of the underworld. As S. G. F. Brandon (The Judgement of the Dead: The Idea of Life after Death in the Major Religions [New York: Scribner, 1967]: 47) puts it: 'In essence the Egyptian mortuary cultus was a magic technique for the acquisition of immortality ... Moral considerations were essentially irrelevant to the successful operation of this technique.' So too Jaroslav Cerny, Ancient Egyptian Religion (London/New York: Hutchinson's University Library, 1952): 90-91; Siegfried Morenz, Egyptian Religion (ET; Ithaca, N.Y.: Cornell University, 1973): 210; A. Jeffrey Spencer, Death in Ancient Egypt (New York: Penguin, 1982): 144. While portrayals of judgement in the Pyramid texts reflect an ethical concern, by the time of the Middle Kingdom, reliance in magic completely replaces a judgement by works (see Breasted, Development of Religion: 37). 
the hands of the god himself or of the demons who carried out his biddings. ${ }^{28}$ Despite the wish to 'become Osiris', the funerary art and texts regularly represent the god of the dead not as a mediator (as Christ is consistently represented in the NT), but as a kind of 'antimediator'. Or, to put it in mythic structuralist terms, Christ and Osiris occupy the opposing roles of 'advocate' and 'adversary'.

Nor could Paul and the worshippers of Osiris have been more different in their respective eschatological outlooks. Unlike the ancient Jews, the Egyptians did not consider time as having a point of termination. History was conceived in static fashion: it was a cyclical, seamless entity proceeding without interruption. This view of history provided the analogy for the Egyptian view of personal existence. Physical death did not mean the end of personhood: death merely marked the immediate transition from one realm to another, both of which endured ad aeternum. Thus the hope of the deceased was not for a better state in the underworld, but for the continuation of earth-like existence in the chthonic realm. ${ }^{29}$ It was through their funerary preparations and rituals that the Egyptians sought to recover, maintain and perpetuate the comforts of earthly life.

This raises two important points. The first, echoing a standard critique of the religionsgeschichtliche approach, is this: to the extent that Paul's notion of resurrection is wedded to and indeed presupposes a certain understanding of history, it is difficult to imagine how Paul could have possibly made recourse to the world of timeless myth. The second objection has to do with the disparate nature of expectations between Paul and the Osirians. The dying wish of the Egyptian was focused on prolonging the familiar, earthly existence in another realm; in this respect, the Egyptian hope was emphatically conservative and retrospective in orientation. Paul's compass pointed not to a retrieval of the earthly life, but to a new and transcendent order of existence.

It is most likely these differences, between Christ and Osiris, between Paul's Jewish eschatology and the Egyptian 'eschatology', that explain the pronounced difference between the Osirian and the early Christians in their respective attitudes regarding death. Whereas Paul expressed his desire 'to depart and be with Christ' (Phil. 1:23) and Ignatius of Antioch yearned to be fed to the lions, no aspiration of this sort can be found anywhere in pre-Christian Egypt. On the contrary,

28 Zandee, Death as an Enemy: 210-11.

29 See Maya Müller, 'Afterlife', in Donald B. Redford, ed., The Oxford Encyclopedia of Ancient Egypt (New York: Oxford University, 2001): 1. 32. 
the Egyptians recoiled at the thought of death. ${ }^{30}$ As the ancient Egyptians are without parallel in their efforts to secure a favorable lot in the afterlife, this arises, paradoxically, not out of a fascination with death, but out of a profound abhorrence of it.

\section{Conclusion}

In sum, the weakness of the 'Osirian theory' is twofold. The parallels prove to be rather unconvincing in their details; but more to the point, given such conspicuous differences in each system of thought, material influence seems altogether improbable. So it seems that the very difficulties that beset the earlier arguments of the Religionsgeschichtlicheschule arise again in connection with Osiris. Just as the distinctive nature of Jewish thought has made it difficult for many scholars to accept the possibility of foreign origins for the Hebrew doctrine of resurrection, so too the profound structural differences between the Egyptian myth and Pauline thought makes Osiris an unlikely factor in the writing of 1 Corinthians $15 .{ }^{31}$

Of course, given my approach to the problem of Paul and Osiris, questions of a more specifically historical nature go untreated. What Osirian traditions, whether oral or written, would have been available to Paul? At what point in his career would have he availed himself of these sources? Other issues remain.

But it is interesting to note, even if in passing, that at the time of Paul, Osirian worship was at its low point. Following initial success under the early Ptolemies in Egypt, the cult of Osiris-Serapis soon waned in popularity - despite making inroads into the rural reaches of Egypt, in the major cities of Egypt the cult went into considerable

\footnotetext{
30 As Morenz (Egyptian Religion: 190) writes: 'We must be careful not to place on the same footing as the words of the Apostle such positive-sounding circumlocutions for death ... They are but euphemisms which demonstrate precisely the emotion we have described, i.e., an aversion even to pronounce the word "death".' See also Hermann Grapow, Die bildlichen Ausdrucke des Ägyptischen (Leipzig, 1924): 18-19.

31 See, e.g., Paul Hoffmann, Die Toten in Christus: Eine religionsgeschichtliche Untersuchung zur paulinischen Eschatologie (NTA NF 2; Münster, 1978): 75 n 111; Otto Kaiser and Eduard Lohse, Tod und Leben (Biblische Konfrontationen; Stuttgart: Kohlhammer, 1977): 79.
} 
decline. ${ }^{32}$ In the first century CE Mediterranean world, there is also substantial loss of interest in the Egyptian god. From the time of Augustus until the time of Trajan, art and epigraphy reflecting interest in Osiris drop off dramatically. ${ }^{33}$ It is only in the later part of the first century, (beginning not much sooner than $69 \mathrm{CE}$ ), when Vespasian's activities in Alexandria spark a renaissance of interest in Egyptian culture, that Osiris makes a 'comeback'. ${ }^{34}$ It is also during this period that Plutarch writes his Isis and Osiris, our only source for understanding the complete Osirian myth. There is not much indication that, prior to Plutarch's writing and the Empire's sudden turn to res aegypticae, a casual non-Egyptian inquirer would have had access to this myth. Much less was Osirianism 'in the air'.

Broaching the possibility of Osirian influence on Paul's thinking in 1 Corinthians 15, however intriguing as a suggestion, in the end creates more problems than it solves. Upon comparing the apostle's doctrine and the outlines of Egyptian thought, the resemblance is anything but striking. Until more convincing allusions to Osirian thought or language can be found in Paul's writing, and until there is a plausible reconstruction of how Paul might have availed himself of Osirian ideas, the raising of Osiris in the Epistles will be no more than the bringing up of a phantom. In the meantime, I submit that the Jewish context provides the best background for understanding Paul and his doctrine of resurrection.

32 See P. M. Fraser, Ptolemaic Alexandria (3 vols; Oxford: Oxford University, 1972): 1. 272-73.

33 Vidman, Isis und Sarapis: 13-15; Wilhelm Hornbostel, Sarapis: Studien zur Überlieferungsgeschichte, den Erscheinungsformen und Wandlungen der Gestalt eines Gottes (EPRO 32; Leiden: Brill, 1970): 44, 358. It is in this period that Diodorus Siculus writes: 'Some are of the opinion that Osiris is Sarapis; others that he is Dionysus, or Pluto, or Ammon; some, that he is Zeus, many that he is Pan. And some say that Sarapis is the god who is called Pluto among the Greeks' (1.25.2). The confusion regarding the identity of Osiris among the Greeks may indirectly support Fraser's (1. 276) contention that the 'Egyptian and extra-Egyptian evidence agree, and enable us to see that the cult of Sarapis was never accepted wholly into the intimate religious consciousness of the Hellenistic world.' So too Ladislav Vidman, Isis und Sarapis bei den Griechen und Römern. Epigraphische Studien zur Verbreitung und zu den Trägern des ägyptischen Kultes (Religionsgeschichtliche Versuche und Vorarbeiten 29; Berlin: de Gruyter, 1970): 13.

34 Vespasian's activities are reported in Tacitus, Hist. 4.81-84. On the re-emergence of Osiris see Vidman, Isis und Sarapis: 104-05; Fraser, Ptolemaic Alexandria: 1.27273; Hornbostel, Sarapis: 291-331. 